J. Perinat. Med. 14 (1986) 293

\section{Antenatal assessment of fetal outcome in pregnant diabetics}

\author{
Wolfgang Burkart, Wolfgang Holzgreve, Wiethold R. Dame, and Herrmann \\ Peter G. Schneider
}

Department of Obstetrics and Gynecology, University Hospital, Münster, Fed. Rep. Germany

\section{Introduction}

One of the major risks in the pregnancy of a diabetic women is the higher prevalence of neonatal problems. In the newborn period hypoglycemia, visceromegaly, polycythemia,hyperbilirubinemia and a characteristic aspect can be typical features of children of diabetic mothers, and their perinatal morbidity and mortality is significantly increased $[4,6]$. Modern management of pregnant diabetic women tries to reach normoglycemia which ideally should be achieved before conception but at least immediately after the diagnosis of pregnancy $[5,10]$. It has been shown that normoglycemia for the full length of pregnancy can be achieved [1] under optimal circumstances with continuous modifications of the insulin dose based on daily measurements of the blood glucose levels by the trained patient and biweekly controls by the physician.

Glycosylated hemoglobin (HbA1) serves as a parameter for long-term assessment of the mean blood glucose, but its value is limited by the fact that during pregnancy an increased number of young erythrocytes are released resulting in false low measurements [2].

WEISS [12] was the first to emphasize the importance of an insulin determination in amniotic fluid for the management of diabetes in preg-

\section{Curriculum vitae}

WOLFGANG BURKART, $M$. D., was born in 1950 in Winterlingen, West Germany. From 1968 to 1980 he studied Chemistry at the Universities of Karlsruhe und Freiburg from which he was graduated in 1980. From 1973 to 1981 he studied medicine at the University of Freiburg and received his M.D. degree in

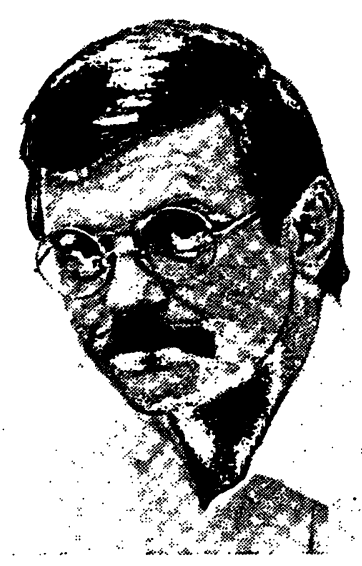
1981. Since 1981 he has been working at the Department of Obstetrics and Gynecology, University of Münster. His main fields of interest are endocrinology, diabetes and obstetrics.

nancy. Because of the long half-life of insulin in amniotic fluid a measurement of this parameter can be considered another index for the longterm diabetic control, and the same applies for C-peptide which is formed in equimolar amounts with insulin during the proteolytic cleavage of proinsulin [3].

Our study was designed to determine which of the three parameters (HbA1, amniotic fluid insulin or C-peptide) has the best prognostic power with regard to neonatal problems due to maternal diabetes. 


\section{Patients and methods}

HbA1-concentrations were measured biweekly in 57 pregnant diabetic women, 2 of which belonged to White's class A, 24 were class B, 12 class $C$ and in 19 patients the severity of diabetes was class $D(n=15)$ or more $(n=4)$. We used the microcolumn method (PanChem, Kleinwallstadt, FRG) because its handling is simple and the results obtained correlate well with the $\mathrm{HbA} 1_{\mathrm{c}}$-determination according to the method of TRIVELLI [11]. Mean values were calculated from the measurements between the 30th and 40th week of pregnancy, and in those patients in whom only a few values could be obtained because of late registration.

For normal control values we used the measurements in 72 non-diabetic patients after the 30th week of pregnancy. In those patients a routine oral glucose tolerance test was performed and venous blood was obtained at the same time for HbA1-determination. Only HbA1 values in those patients were used whose $100 \mathrm{~g}$ glucose tolerance test was not pathologic according to the criteria of O'SULLIVAN [9]. The HbA1 measurements were performed between the 30th and 40th week of pregnancy and up to three days after delivery.

The present study includes pregnancies in which an amniocentesis between the 34th and 37th week was consented to by the patient. This constitutes about $52 \%$ of the total number of diabetic pregnancies in our center during the observation period from 1981-1984. Using commercially available test kits we measured amniotic fluid insulin (Serono, Freiburg, FRG) and C-peptide (Byk Malinckrodt). The values were assessed following the curves described before [3]. There were no complications from the amniocenteses. For counselling purposes we used a risk figure of $0.3 \%$ [7].

The newborns were evaluated routinely by the pediatricians according to their clinical presentation and glucose requirements post partum. The minimum requirements for classifying a child as having "major symptoms" were hypoglycemia of less than $30 \mathrm{mg} \%$ for more than 7 days and body weight above the 90th percentile. Most of these children had visceromegaly and/ or hyperbilirubinemia, some exhibited increased hematocrit values, cardiomyopathy or hypocalcemia. One child suffered from respiratory distress syndrome. Minor alterations in blood glucose levels which could be controlled by frequent meals were not considered.

\section{Results}

The mean value of all HbA1-measurements of those patients who had normal $100 \mathrm{~g}$ oGTT was $6.4 \pm 1.1 \%$ in our series. For the evaluation of the insulin and C-peptide levels in the 34 th -37 th pregnancy weeks those values were considered normal which corresponded to the 99th percentile of a distribution derived from the concentration of these peptides in 275 nondiabetic pregnancies. These limits were found to be $23 \mu \mathrm{U} / \mathrm{ml}$ insulin and $3 \mathrm{ng} / \mathrm{ml} \mathrm{C}$-peptide (table I). The cut-off points of $18 \mu \mathrm{U} / \mathrm{ml}$ insulin and $2.6 \mathrm{ng} / \mathrm{ml} \mathrm{C}$-peptide used in tables II and III $a, b$ are derived from the mean values of

Table I. Predictability of neonatal morbidity in infants of diabetic mothers.

\begin{tabular}{|c|c|c|c|c|c|c|c|}
\hline \multirow[t]{2}{*}{ parameter } & \multirow[t]{2}{*}{ limits } & \multicolumn{2}{|c|}{ children without major symptoms } & \multicolumn{2}{|c|}{ children with major symptoms } & \multicolumn{2}{|c|}{ specificity sensitivity } \\
\hline & & correctly low & false elevated & correctly elevated & false low & & \\
\hline insulin & $\begin{array}{l}23 \mu \mathrm{U} / \mathrm{ml} \\
18 \mu \mathrm{U} / \mathrm{ml}\end{array}$ & $\begin{array}{l}96 \%(n=46) \\
83 \%(n=40)\end{array}$ & $\begin{array}{r}4 \%(n=2) \\
17 \%(n=8)\end{array}$ & $\begin{array}{l}56 \%(\mathrm{n}=5) \\
78 \%(\mathrm{n}=7)\end{array}$ & $\begin{array}{l}44 \%(n=4) \\
22 \%(n=2)\end{array}$ & $\begin{array}{l}96 \% \\
83 \%\end{array}$ & $\begin{array}{l}56 \% \\
78 \%\end{array}$ \\
\hline C-peptide & $\begin{array}{r}3 \mathrm{ng} / \mathrm{ml} \\
2,6 \mathrm{ng} / \mathrm{ml}\end{array}$ & $\begin{array}{l}88 \%(n=42) \\
75 \%(n=36)\end{array}$ & $\begin{array}{l}12 \%(n=6) \\
25 \%(n=12)\end{array}$ & $\begin{array}{l}50 \%(n=4) \\
50 \%(n=4)\end{array}$ & $\begin{array}{l}50 \%(n=4) \\
50 \%(n=4)\end{array}$ & $\begin{array}{l}88 \% \\
75 \%\end{array}$ & $\begin{array}{l}50 \% \\
50 \%\end{array}$ \\
\hline HbA1 & $7,5 \%$ & $77 \%(n=37)$ & $23 \%(n=11)$ & $44 \%(n=4)$ & $56 \%(n=5)$ & $77 \%$ & $44 \%$ \\
\hline
\end{tabular}


Table II. Prediction of a healthy child and of major symptoms.

\begin{tabular}{lllllll}
\hline & \multicolumn{3}{l}{ Prediction of a healthy child } & \multicolumn{2}{l}{ Prediction of major symptoms } \\
\hline parameter & limit & $\begin{array}{l}\text { proportion of } \\
\text { normal values* }\end{array}$ & $\begin{array}{l}\text { predictive } \\
\text { value }\end{array}$ & limit & $\begin{array}{l}\text { proportion } \\
\text { of elevated } \\
\text { values** }\end{array}$ & $\begin{array}{l}\text { predictive } \\
\text { value }\end{array}$ \\
\hline insulin & $23 \mu \mathrm{U} / \mathrm{ml}$ & $46 / 50$ & $92 \%$ & $18 \mu \mathrm{U} / \mathrm{ml}$ & $7 / 15$ & $47 \%$ \\
& $18 \mu \mathrm{U} / \mathrm{ml}$ & $40 / 42$ & $95 \%$ & $23 \mu \mathrm{U} / \mathrm{ml}$ & $5 / 7$ & $72 \%$ \\
C-peptide & $3 \mathrm{ng} / \mathrm{ml}$ & $42 / 46$ & $91 \%$ & $3 \mathrm{ng} / \mathrm{ml}$ & $4 / 10$ & $40 \%$ \\
& $2,6 \mathrm{ng} / \mathrm{ml}$ & $36 / 40$ & $90 \%$ & $2,6 \mathrm{ng} / \mathrm{ml}$ & $4 / 16$ & $25 \%$ \\
HbA1 & $7,5 \%$ & $37 / 42$ & $88 \%$ & $7,5 \%$ & $4 / 15$ & $27 \%$ \\
& & & & $9 \%$ & $4 / 9$ & $44 \%$ \\
\hline
\end{tabular}

* ratio of correctly diagnosed normal values over total of normal values

** ratio of correctly diagnosed elevated values over total of elevated values

Table IIIa. Prediction of a healthy child based on more than one parameter.

\begin{tabular}{lll}
\hline condition & $\begin{array}{l}\text { correct } \\
\text { prediction* }\end{array}$ & $\begin{array}{l}\text { predictive } \\
\text { value }\end{array}$ \\
\hline
\end{tabular}

insulin below $18 \mu \mathrm{U} / \mathrm{ml}$

and $\mathrm{HbA1}$ below 7,5\%

$29 / 30 \quad 97 \%$

insulin below $18 \mu \mathrm{U} / \mathrm{ml}$,

HbA1 below 7,5\% and

C-peptide below $3 \mathrm{ng} / \mathrm{ml} \quad 28 / 28 \quad 100 \%$

insulin below $18 \mu \mathrm{U} / \mathrm{ml}$ and

C-peptide below $3 \mathrm{ng} / \mathrm{ml} \quad 35 / 37 \quad 95 \%$

Table IIIb. Prediction of major symptoms based on more than one parameter.

\begin{tabular}{lll}
\hline condition & $\begin{array}{l}\text { correct } \\
\text { prediction* }\end{array}$ & $\begin{array}{l}\text { predictive } \\
\text { value }\end{array}$ \\
\hline $\begin{array}{l}\text { insulin above } 18 \mu \mathrm{U} / \mathrm{ml} \\
\text { and HbA1 above } 7.5 \%\end{array}$ & $3 / 5$ & $60 \%$ \\
$\begin{array}{l}\text { insulin above } 18 \mu \mathrm{U} / \mathrm{ml} \text { and } \\
\text { C-peptide above } 3 \mathrm{ng} / \mathrm{ml}\end{array}$ & $4 / 7$ & $57 \%$ \\
$\begin{array}{l}\text { insulin above } 18 \mu \mathrm{U} / \mathrm{ml}, \\
\text { C-peptide above } 3 \mathrm{ng} / \mathrm{ml}\end{array}$ & & \\
and HbA1 above $7.5 \%$ \\
$\begin{array}{l}\text { insulin above } 23 \mu \mathrm{U} / \mathrm{ml}, \\
\text { C-peptide above } 3 \mathrm{ng} / \mathrm{ml} \\
\text { and HbA1 above } 7.5 \%\end{array}$ & $2 / 3$ & $66 \%$ \\
$\begin{array}{l}2 \text { of } 3 \text { parameters } \mathrm{above} \\
\text { limit }(18 \mu \mathrm{U} / \mathrm{ml}, 3 \mathrm{ng} / \mathrm{ml},\end{array}$ & $2 / 3$ & $66 \%$ \\
$7.5 \%)$ & $6 / 11$ & $54 \%$
\end{tabular}

* number of correctly predicted cases over total of cases fulfilling conditions those concentrations found in healthy children of diabetic mothers. The rate of correct predictions is given in the tables.

Nine of the 57 children whose mothers had a determination of glycosylated hemoglobin and an amniocentesis, had major neonatal complications. The mean glucose application in those children during the first 24 hours was $7.8 \mathrm{mg} /$ $\mathrm{kg}$ body weight/minute as opposed to $4.2 \mathrm{mg}$ in healthy children of diabetic mothers.

\section{Discussion}

Table I indicates that $75-96 \%$ of the children without neonatal symptomatology had normal values of one of the three parameters, depending on the cut-off points chosen. The narrower the normal range is defined, the lower is the number of children with normal values. If the insulin cut-off point is lowered from 23 to $18 \mu \mathrm{U} / \mathrm{ml}$, the percentage of children with normal values of amniotic fluid insulin decreases from 96 to $83 \%$. C-peptide shows a similar decrease of normal values in non-symptomatic patients from 88 to $75 \%$. The rate of values measured correctly as elevated increases from 56 to $78 \%$ in the case of insulin.

In the case of C-peptide the introduction of a lower limit increases the rate of false low values, the rate of correctly or falsely increased values remains unchanged. We conclude from our data 
that the upper limits of the three parameters should be $7.5 \%$ for $\mathrm{HbA} 1,18 \mu \mathrm{U} / \mathrm{ml}$ for amniotic fluid insulin and $3.0 \mathrm{ng} / \mathrm{ml}$ for C-peptide.

When trying to derive a prognosis from these elevated values and to test the predictive value of all three parameters, the results in table II have to be considered. It is obvious that the prediction of a healthy baby is easy. Depending on the parameter chosen a correct prediction can be expected in 83 to $95 \%$ of all cases. The determination of amniotic fluid insulin is associated with a predictive value based on an upper limit of $18 \mu \mathrm{U} / \mathrm{ml}$. The prediction of newborn morbidity can also be achieved using the same criteria. For this purpose the determination of amniotic fluid insulin is most useful with values higher than $23 \mu \mathrm{U} / \mathrm{ml}$ being clearly pathologic. The determination of $\mathrm{C}$-peptide and HbA1 is less useful but values higher than $9 \%$ HbA1 can be considered pathologic in $44 \%$ of the cases.

Taking into account more than one single parameter, the accuracy of the prediction "healthy child" reaches $100 \%$ (table IIIa, b). The accuracy of the prediction of major neonatal problems cannot be further increased, it ranges between 54 and $66 \%$ if all three parameters are assessed simultaneously. It should be taken into account that the significance of the results is limited due to the sample size.

According to our results the concentration of insulin in amniotic fluid is the most reliable parameter for the evaluation of developing fetal impairment. This is in contrast to LIN et al [8], who found $\mathrm{C}$-peptide to be more reliable. It is obvious that a statement can be made with much higher certainty when the other parameters are also taken into account. For the exclusion of severe neonatal disease $\mathrm{HbA1}$, amniotic fluid insulin and $C$-peptide have to be lower than $7.5 \%, 18 \mu \mathrm{U} / \mathrm{ml}$ and $3.0 \mathrm{ng} / \mathrm{ml} \mathrm{re}-$ spectively. If two of these three parameters are below these limits, a fetal impairment can be excluded with more than $90 \%$ certainty.

An amniotic fluid insulin level of more than $23 \mu \mathrm{U} / \mathrm{ml}$ can be considered as a strong indicator of neonatal disease. The accuracy of this prediction is more than $70 \%$. An increase of the insulin level to more than $18 \mu \mathrm{U} / \mathrm{ml}$ has to be evaluated by taking the other parameters into account: A fetal compromise has to be assumed in more than $60 \%$ of the cases if all three values are increased. If only two values are elevated, the accuracy of the prediction is lowered to about $50 \%$.

\section{Summary}

The predictive value of three parameters (amniotic fluid insulin and C-peptide, and HbA1) in prognosticating major neonatal symptomatology was investigated in 57 pregnancies of diabetic women. The prediction of a healthy neonate can be achieved with a $90 \%$ accuracy by measurement of the amniotic fluid insulin alone. The correct prognosis for a child with major neonatal problems due to maternal diabetes can be made with
$70 \%$ certainty using the same method. All other parameters can be judged less valuable based on our results. By using more than one of those parameters mentioned, the prediction of a healthy child can be made more correctly with a certainty of almost $100 \%$. The accuracy in predicting a child with major symptoms cannot be increased any further.

Keywords: Amniotic fluid C-peptide, amniotic fluid insulin, HbA1, infants of diabetic mothers.

\section{Zusammenfassung}

Antenatale Vorhersage des Neugeborenenzustandes bei schwangeren Diabetikerinnen

In 57 Schwangerschaften von Diabetikerinnen wurde der prädiktive Wert dreier Parameter: Fruchtwasser-Insulin,
Fruchtwasser-C-Peptid und HbA1 untersucht. Die Vorhersage eines gesunden Neugeborenen ist durch die Bestimmung des Fruchtwasserinsulingehaltes mit einer Sicherheit von über $90 \%$ möglich, die eines Kindes mit 
ausgeprägter diabetischer Fetopathie jedoch nur mit $70 \%$ iger Sicherheit. Bei den anderen Parametern ist der prädiktive Wert geringer.

Durch die gleichzeitige Wertung mehrerer der obengenannten Parameter kann die Zuverlässigkeit der Vorher- sage eines gesunden Kindes auf nahezu $100 \%$ gesteigert werden, die Vorhersage eines kranken Kindes wird nicht sicherer als durch die Bestimmung von Fruchtwasserinsulin allein.

Schlüsselwörter: Diabetische Fetopathie, Fruchtwasser-C-Peptid, Fruchtwasserinsulin, HbA1.

\section{Résumé}

\section{Estimation antenatale du devenir foetal chez les diabéti-} ques enceintes

On a exploré la valeur prédictive de trois paramètres (insuline dans le liquide amniotique, peptide $\mathrm{C}$ et $\mathrm{Hb} \mathrm{A} 1$ ) face à la symptomatologie néonatale majeure au cours de 57 grossesses chez des femmes diabétiques. On peut prévoir un nouveau-né en bonne santé avec une fiabilité de $90 \%$ en déterminant uniquement l'insuline dans le liquide amniotique. La prévision correcte d'un enfant qui présentera des problèmes néonataux majeurs se- condaires au diabète maternel est possible avec une fiabilité de $70 \%$ en utilisant la même méthode. En se fondant sur nos résultats, on peut juger tous les autres paramètres comme moins valables.

En utilisant plus d'un des paramètres mentionnés, on peut prédire correctement un enfant en bonne santé avec une fiabilité proche de $100 \%$. Toutefois, la fiabilité de la prévision d'un enfant qui présentera des symptomes majeurs, ne peut pas être augmenté de la sorte.

Mots-clés: Enfants de mères diabétiques, HbA1, insuline dans le liquide amniotique, peptides $\mathrm{C}$ du liquide amniotique.

\section{References}

[1] Berger M, I MühlHAUSER, V JöRgENS: Die Evaluation der Diabetiker-Edukation. Fortschr Med 101 (1983) 212

[2] BUNN F: Nonenzymatic Glycosylation of Protein: It's Role in Diabetes mellitus. In: BRodofF B, S Bleicher (eds): Diabetes mellitus and Obesity. Williams and Wilkins, Baltimore 1982

[3] BURKART W, WR DAME, E RUPPIN, HPG SCHNEIDER: Die Bedeutung von Hormonen im Fruchtwasser: I. Insulin und C-Peptid. Geburtshilfe Frauenheilkd 44 (1984) 417

[4] Dominick HCH, W BuRKarT: Kinder diabetischer Mütter. Monatsschr Kinderheilkd 132 (1984) 886

[5] Funrmann K: Diabetes Control and Outcome in the Pregnant Patient. In: Peterson CM (ed): Diabetes Management in the 80 's. Praeger, New York 1982

[6] Hollingsworth DR: Pregnancy, Diabetes and Birth. Williams and Wilkins, Baltimore 1984

[7] Holzgreve W, M Hansmann: Erfahrungen mit der "free hand needle". Technik bei 3215 Amniocentesen im 2. Trimenon zur pränatalen Diagnostik. Gynaekologe 17 (1984) 77-82

[8] Lin C, P River, A Moawad, R Lowenschu, P Blix, A Abraham, A Rubenstein: Prenatal Assess- ment of Fetal Outcome by Amniotic Fluid C-peptide Levels in Pregnant Diabetic Women. Am J Obstet Gynecol 141 (1981) 671

[9] O'Sullivan JB, C Mahan: Criteria for the Oral Glucose Tolerance Test in Pregnancy. Diabetes 13 (1964) 278

[10] Roversi GD, M Gargiulo, U Nicolini, E Pedretti, A Marini, U Barbarini, P Peueff: A New Approach to the Treatment of Diabetic Pregnant Women, Report of 479 Cases. Am J Obstet Gynecol 135 (1979) 567

[11] Trivelli LA, HN RanNey, HT LaI: Hemoglobin Components in Patients with Diabetes mellitus. N Engl J Med 195 (1976) 417

[12] Weiss PA, W Lichtenegger, $R$ Winter, $P$ PÜRSCHNER: Insulin Levels in Amniotic Fluid. Management of Pregnancy in Diabetes. Obstet Gynecol 51 (1978) 393

Received March 19, 1985. Revised October 29, 1985. Accepted January 6, 1986.

Dr. Wolfgang Burkart

Universitäts-Frauenklinik

Albert-Schweitzer-Str. 33

D-4400 Münster, Fed. Rep. Germany 